\section{Growth of Native Aromatic Xerophytes in an Extensive Mediterranean Green Roof as Affected by Substrate Type and Depth and Irrigation Frequency}

\author{
Maria Papafotiou', Niki Pergialioti, and Lamprini Tassoula \\ Laboratory of Floriculture and Landscape Architecture, Department of Crop \\ Science, Agricultural University of Athens, Iera Odos 75, 11855 Athens, \\ Greece
}

\section{Ioannis Massas}

Laboratory of Agricultural Chemistry and Soil Science, Department of Natural Resources Management and Agricultural Engineering, Agricultural University of Athens, Iera Odos 75, 11855 Athens, Greece

\section{Georgios Kargas}

Laboratory of Agricultural Hydraulics, Department of Natural Resources Management and Agricultural Engineering, Agricultural University of Athens, Iera Odos 75, 11855 Athens, Greece

Additional index words. Artemisia absinthium, drought, grape marc compost, Helichrysum italicum, Helichrysum orientale, peat, perlite, semiarid

\begin{abstract}
Green roofs could be a way to increase vegetation in the center of old Mediterranean cities. The need for conservation of local character and biodiversity requires the use of native plant species, whereas the deficiency of water, particularly in semiarid regions, requires the use of species with reduced irrigation needs. Moreover, the aged buildings lead to the use of lightweight green roof constructions. Therefore, research was undertaken to investigate the possibility of using three Mediterranean aromatic xerophytes, Artemisia absinthium L., Helichrysum italicum Roth., and H. orientale L., at an extensive green roof in Athens, Greece. Simultaneously, the possibility of using locally produced grape marc compost was investigated. Substrate type and depth and irrigation frequency effects on growth of these species were studied. Rooted cuttings were planted mid-May in plastic containers with a green roof infrastructure fitted (moisture retention and protection of the insulation mat, drainage layer, and filter sheet) and placed on a fully exposed third floor flat roof at the Agricultural University of Athens. Two types of substrates were used, grape marc compost:soil:perlite $(2: 3: 5, \mathrm{v} / \mathrm{v})$ and peat:soil:perlite (2:3:5, v/v, as a control), as well as two substrate depths, 7.5 (shallow) and $15 \mathrm{~cm}$ (deep), and two irrigation frequencies, sparse (5 or 7 days in shallow and deep substrate, respectively) and normal ( 3 or 5 days in shallow and deep substrate, respectively). Increased contents of macroelements, total phosphorus $(P)$ and potassium $(K)$ in particular, were recorded in the compost-amended substrate, whereas both substrates had similar physical properties. Plant growth was recorded from May to October. The deep compost-amended substrate, independent of irrigation frequency, resulted in taller plants with bigger diameter and aboveground dry weight in all species. However, a remarkable result was that shallow compost-amended substrate with sparse irrigation resulted in similar or even bigger plant growth of all plant species compared with deep peat-amended substrate with normal irrigation. Thus, all three species were found suitable for use in Mediterranean extensive or semi-intensive green roofs, whereas the use of grape marc compost in the substrate allowed for less water consumption and the reduction of substrate depth without restriction of plant growth at the establishment phase and the first period of drought.
\end{abstract}

The intense urbanization of recent decades has led to the development of huge cities, even in the Mediterranean, where large smooth areas, usually offered for the development of big cities, are not commonly

Received for publication 05 July 2013. Accepted for publication 25 Aug. 2013.

${ }^{1}$ To whom reprint requests should be addressed; e-mail mpapaf@aua.gr. the ecological and technical functions of this technology (Benvenuti and Bacci, 2010; Fioretti et al., 2010; Savi et al., 2013).

In the last decade mainly, a number of research works, reviews, and books (Dunnett and Kingsbury, 2008; Getter and Rowe, 2006; Oberndorfer et al., 2007) refer to ecosystem services provided by green roofs in urban areas such as improved stormwater management (Fioretti et al., 2010; Nagase and Dunnett, 2012), thermal insulation and energy conservation (Jaffal et al., 2012), reduction of the urban heat island effect (Bowler at al., 2010; Mackey et al., 2012), mitigation of air pollution (Currie and Bass, 2008), $\mathrm{CO}_{2}$ sequestration (Getter et al., 2009; Li et al., 2010), increased biodiversity and provision of habitats (Maclvor and Lundholmb, 2011) as well as increased aesthetic value of buildings and the city overall. Furthermore, green roofs could contribute to the socialization of the multistory building tenants in dense cities, replacing the traditional house courtyard or terrace as an assembly place. In addition, the visitation or even the volunteer work of some people, e.g., elderly or children, at a green roof could support their psychosomatic health and provide environmental education (Kweon et al., 1998).

Major parameters that should be taken under consideration before applying green roof systems in Mediterranean regions are water availability, particularly in those areas with semiarid climate, biodiversity, and local character preservation. The use of native xerophytes in Mediterranean green roofs could fulfill all these conditions (Benvenuti and Bacci, 2010). A number of works refer to the ability of certain plant species to cope with drought in green roofs (Benvenuti and Bacci, 2010; Kotsiris et al., 2012; Nagase and Dunnett, 2010; Nektarios et al., 2011; Thuring et al., 2010). Even in regions characterized by cooler and wet climates, the growth environment of green roofs is considered severe as a result of high exposure to solar radiation, wind, wide temperature fluctuations, and limited water availability. Therefore, Sedum taxa have been widely investigated and are a popular choice for extensive green roofs, because these plants combine shallow root systems with high tolerance to drought resulting from crassulacean acid metabolism (Durhman et al., 2007; Rowe et al., 2012). Recognizing green roofs as tools for augmentation of urban biodiversity and habitats (Cook-Patton and Bauerle, 2012; Lundholm and Peck, 2008), a diversity of species capable to establish meadows on extensive green roofs have raised the attention of researchers (Dvorak and Volder, 2010; Maclvor and Lundholmb, 2011; Nagase and Dunnett, 2010, 2013). Apart from biodiversity reasons, mixing multiple species in a green roof was shown to enhance plant performance and ecological services through optimal water loss and roof surface cooling (Butler and Orians, 2011; Dvorak and Volder, 2010). Also plant species with taller height, larger diameter, and larger shoot and root biomass, as grasses and forbs, were more effective than sedum in reducing water runoff 
from green roofs (Nagase and Dunnett, 2012).

The weight of a green roof is another issue that should be taken into consideration in constructions, particularly in the Mediterranean, where most cities are composed of aged buildings that possibly will not support a heavy green roof. Green roof weight depends mainly on the substrate type and depth. Therefore, it is desirable to identify plant species and substrate types to ensure satisfactory growth in shallow substrate. Interestingly, the Mediterranean xerophyte Dianthus fruticosus survived through summer in southern Greece with minimum irrigation $\left(15 \% \mathrm{E}_{\mathrm{pan}}\right)$, even at $7.5-\mathrm{cm}$ substrate depth (Nektarios et al., 2011).

The ideal substrate should be lightweight, well drained with adequate water and nutrientholding capacity and should not break down over time (Fassman et al., 2010; FLL, 2010). According to the FLL (2010) guidelines, organic content for an extensive green roof should be up to $20 \%$ by volume. Higher levels of organic matter are not recommended because it might cause shrinkage of the substrate over time and can result in increased nitrogen (N) and P runoff (Getter and Rowe, 2006). Furthermore, compost-rich substrates may result in plants with increased foliage, prone to increased transpiration and thus more susceptible to water stress conditions (Nagase and Dunnett, 2011).

Often the organic matter of green roof substrates is composed of peat, bark compost, or green waste compost. Peat is used because of its high waterholding capacity and readily available water, high cation exchange capacity, and low bulk density (Ampim et al., 2010; Fassman et al., 2010). However, its use in horticulture has become an environmental issue, because it is considered a non-renewable resource that should be preserved (Alexander et al., 2008). A parallel environmental issue is the disposal of agroindustrial wastes; composting being part of the solution to this problem. Locally available recycled materials are recommended for use in green roof substrates (Getter and Rowe, 2006; Molineux et al., 2009) contributing to the reduction of construction cost and carbon footprint. Grape marc compost is found in large amounts in the traditionally wine-producing Mediterranean region and has been used efficiently for greenhouse horticulture (Papafotiou et al., 2011a, 2011b; Reis et al., 2001).

In the present work, we investigated the possibility of using native aromatic xyrophytes in extensive green roofs in semiarid Mediterranean regions, simultaneously with the possibility of using locally produced grape marc compost as a substrate component, to support urban biodiversity and carbon footprint reduction, preserving local character and increasing enjoyment. Aromatic plants, apart from evoking memories by their aroma, particularly for elderly persons, can attract wild life such as butterflies and bees, having simultaneously repellent effects on mosquitoes (Fussell and Corbet, 1992; Lafuma et al., 2001). Three shrubby (40 to $50 \mathrm{~cm}$ height), aromatic, Mediterranean xerophytes, members of the Asteraceae family, Artemisia absinthium L., Helichrysum italicum Roth., and $H$. orientale L., were selected for evaluation as for their adaptation to extensive green roof conditions in Athens, Greece. These plant species grow naturally on rocky sunny slopes, have fibrous roots, gray leaves, and bear numerous yellow flower heads from April to June in $H$. orientale and June to September in H. italicum and A. absinthium (Polunin, 1981). No information was found on the type of photosynthesis of these species; however, their origin and their morphological characteristics, as well as information on related species (Nelson, 2012), indicate that they should be $\mathrm{C} 3$ plants. They are grown as ornamental plants in many countries, whereas the flower heads of both Helichrysum retain their color after picking and are used in dried flower arrangements. All three species are also valuable for pharmaceutical and aromatic purposes (Chiasson et al., 2001; Roussis et al., 2000; Sala et al., 2002). Therefore, the growth of $A$. absinthium, H. italicum, and $H$. orientale on an east Mediterranean green roof was evaluated in combination with the use of grape marc compost in the substrate under two substrate depths and two irrigation frequencies.

\section{Materials and Methods}

Experimental setup. The study was conducted on a fully exposed flat roof of a threestory building at the Agricultural University of Athens in the city center of Athens (lat. $37^{\circ} 59^{\prime} \mathrm{N}$, long. $23^{\circ} 42^{\prime} \mathrm{E}$ ) from 21 May 2009 to 21 Oct. 2009. Rooted cuttings of $A$. absinthium L., $H$. italicum Roth., and $H$. orientale L. (Marigold Plants S.A.) were planted in shallow or deep (15-cm or $23-\mathrm{cm}$ depth, respectively) plastic containers, $60 \mathrm{~cm}$ long, $40 \mathrm{~cm}$ wide, with shallow $(7.5 \mathrm{~cm})$ or deep $(15 \mathrm{~cm})$ substrate depth, respectively. Four drainage holes were drilled in each container. Within each container, a simulation of a green roof system was constructed with the use of the appropriate layers. The moisture retention and protection of the insulation mat, a 3-mm thick synthetic cloth made of non-rotting synthetic polyester fibbers and weighing $0.32 \mathrm{~kg} \cdot \mathrm{m}^{-2}$ (TSM32; Zinco, Egreen, Athens, Greece), was placed at the base of the container. This layer is used to protect the waterproofing membrane of a green roof against mechanical damage and at the same time acts as a water reservoir by retaining $4 \mathrm{~L} \cdot \mathrm{m}^{-2}$ of water (manufacturer data sheet). The drainage layer of recycled polyethylene with a $25-\mathrm{mm}$ high core and a weight of $1.5 \mathrm{~kg} \cdot \mathrm{m}^{-2}$ (FD25; Zinco, Egreen) with water-retaining troughs and openings for ventilation was placed over the protection cloth. The drainage layer had the capacity to store $3 \mathrm{~L} \cdot \mathrm{m}^{-2}$ serving as additional water storage (manufacturer data sheet). The drainage layer was covered by a filter sheet that was a non-woven geotextile (SF; Zinco, Egreen) made of thermally strengthened polypropylene, having $0.6 \mathrm{~mm}$ thickness,
$0.1 \mathrm{~kg} \cdot \mathrm{m}^{-2}$ weight, effective opening width $\mathrm{d}_{90 \%}=95 \mu \mathrm{m}$, and $0.07 \mathrm{~m} \cdot \mathrm{sec}^{-1}$ permeability. The geotextile was turned upward at the four sides of the container and fixed to prevent the movement of substrate particles toward the geocomposite drainage layer from the sides. On top of the geotextile was placed the plant growing substrate. A root repellent membrane (DIADEM FLW800; DIADEM GREECE, Athens, Greece) was placed on top of the building roof between the roof and the containers.

Two types of substrate mixes were used, one containing grape marc compost $(\mathrm{C})$ and the other (control) containing peat (T) (Highmore with adjusted $\mathrm{pH}$; Klansmann-Deilmann Gmbh, Geeste, Germany), which were C: soil $(\mathrm{S})$ : perlite $(\mathrm{P})$ and $\mathrm{T}: \mathrm{S}: \mathrm{P}$ in a volumetric proportion of 2:3:5, respectively. The perlite particles were 1 to $5 \mathrm{~mm}$ in diameter (Perloflor; ISOCON S.A., Athens, Greece); the soil had $86.9 \%$ sand, $3 \%$ loam, and $10.2 \%$ clay; the grape marc compost was produced locally and was 20 months old. The method routinely used for composting grape marc in Greece is as follows: compost piles of trapezoid profile ( $\approx 2.5 \mathrm{~m}$ base width, $1.5 \mathrm{~m}$ top width, $1 \mathrm{~m}$ height, and 10 to $15 \mathrm{~m}$ length) are made in September to October. The piles are turned over every 2 to 3 weeks for the first 3 months. The humidity of the pile is maintained over $50 \%$ by the natural rain events (rain events occur quite often during the fall-winter period in Greece). After this procedure, the compost is mature in spring.

Soil was added in the experimental substrates based on the argument that it could "act as a bridging factor between substrate particles that would increase water-holding capacity at low tensions, thus improving plant growth in semi-arid regions" (Nektarios et al., 2011).

Two irrigation frequencies, normal ( 3 or 5 $\mathrm{d}$ in shallow and deep substrate, respectively) and sparse (5 or $7 \mathrm{~d}$ in shallow and deep substrate, respectively), were applied. Therefore, eight treatments were applied $\left(2_{\text {substrates }}\right.$ $\times 2_{\text {depths }} \times 2_{\text {irrigations }}=$ eight treatments $)$. In each treatment, 12 plants of each species were used. In each container, four plants of the same species were planted. Thus, three containers per treatment for each plant species were used ( 24 containers per species, 72 in total) and 96 plants per species (288 in total).

A complete water-soluble fertilizer (Nutrileaf 60, 20-20-20; Miller Chemical and Fertilizer Corp., Hanover, PA), $20 \mathrm{~N}-$ $11.27 \mathrm{P}-16.6 \mathrm{~K}-0.025 \mathrm{Mg}-0.02 \mathrm{~B}-0.05 \mathrm{Cu}-$ $0.10 \mathrm{Fe}-0.05 \mathrm{Mn}-0.001 \mathrm{Mo}-0.05 \mathrm{Zn}\left(2 \mathrm{~g} \cdot \mathrm{L}^{-1}\right.$, $400 \mathrm{mg} \cdot \mathrm{L}^{-1} \mathrm{~N}, 50 \mathrm{~mL}$ of solution per plant) was applied to all experimental plants on 25 June because both species of Helichrysum showed symptoms of chlorosis in older leaves resembling magnesium deficiency. H. orientale plants were fertilized once more on 9 Sept. because they showed chlorosis symptoms again. The symptoms disappeared soon after each fertilization.

Irrigation scheduling and meteorological data. The first 2 weeks after planting irrigation 
was applied manually allow to water runoff the container every $2 \mathrm{~d}$ for the plants to overcome transplant stress. On 5 June the plants were irrigated and then were exposed to water stress to determine how many days they could tolerate without irrigation. Daily measurements of the substrate moisture $(\% \mathrm{v} / \mathrm{v})$ were taken (three measurements from each container at 1700 to $1800 \mathrm{HR}$ ) using a handheld time domain reflectometry moisture meter (HH2; Delta-T devices, Cambridge, U.K.) with a soil moisture dielectric sensor (WET2; Delta-T devices) inserted from the surface that measured $65 \mathrm{~mm}$ in depth and $45 \mathrm{~mm}$ in width. It was found that plants, particularly $A$. absinthium, in shallow substrates started showing water stress symptoms $5 \mathrm{~d}$ after irrigation and in deep substrates $7 \mathrm{~d}$ after irrigation. On those days the mean substrate moisture measured was $6.5 \%$ to $8.5 \% \mathrm{v} / \mathrm{v}$. Therefore, these were decided to be the "sparse" irrigation frequency. The "normal" irrigation frequency was decided to be when substrate moisture was $\approx 14 \%$ to $17 \% \mathrm{v} / \mathrm{v}$ and this was measured on Day 3 and Day 5 for shallow and deep substrates, respectively. Substrate moisture

Table 1 . The average monthly air temperature, relative humidity and total radiation, the total monthly rainfall, and days of rainfall for the study period.

\begin{tabular}{lccccc}
\hline Month & $\begin{array}{c}\text { Avg air } \\
\text { temp }\left({ }^{\circ} \mathrm{C}\right)\end{array}$ & $\begin{array}{c}\text { Relative } \\
\text { humidity }(\%)\end{array}$ & $\begin{array}{c}\text { Total radiation } \\
\left(\mathrm{MJ} \cdot \mathrm{m}^{-2}\right)\end{array}$ & $\begin{array}{c}\text { Total } \\
\text { rainfall }(\mathrm{mm})\end{array}$ & $\begin{array}{r}\text { Days of } \\
\text { rainfall }\end{array}$ \\
\hline May & 21.40 & 53 & 24.23 & 0.0 & 0 \\
June & 25.70 & 49 & 28.50 & 0.6 & 2 \\
July & 28.70 & 46 & 27.62 & 0.8 & 1 \\
August & 28.00 & 42 & 24.99 & 0.8 & 1 \\
September & 22.70 & 63 & 18.03 & 74.0 & 10 \\
October & 19.20 & 71 & 12.81 & 42.8 & 6 \\
\hline
\end{tabular}

Table 2. Physicochemical properties of the substrates and their components. ${ }^{z}$

\begin{tabular}{lcccrr}
\hline Substrate/component & $\begin{array}{c}\text { Bulk density } \\
\left(\mathrm{g} \cdot \mathrm{cm}^{-3}\right)\end{array}$ & EAW $(\% \mathrm{v} / \mathrm{v})$ & $\begin{array}{c}\text { Total porosity } \\
(\% \mathrm{v} / \mathrm{v})\end{array}$ & $\mathrm{pH}$ & $\mathrm{EC}\left(\mu \mathrm{S} \cdot \mathrm{cm}^{-1}\right)$ \\
\hline 2T:3S:5P & 0.540 & 11.1 & 55.0 & 7.5 & 111 \\
2C:3S:5P & 0.640 & 10.5 & 61.0 & 7.8 & 144 \\
T & 0.139 & 13.3 & 70.2 & 7.0 & 38 \\
C & 0.390 & 6.3 & 65.0 & 7.8 & 1287 \\
S & 1.470 & 2.7 & 40.7 & 8.3 & 103 \\
\hline
\end{tabular}

${ }^{\mathrm{z}} \mathrm{pH}$ and electrical conductivity (EC) were determined in 1:5 volume water extracts. Easily available water (EAW) was determined from water retention curves as the quantity of water released when the suction was increased from 10 to $50 \mathrm{~cm}$.

$\mathrm{T}=$ peat $\mathrm{S}=$ soil $\mathrm{P}=$ perlite $\mathrm{C}=$ grape marc compost, ratios by volume.

Table 3. Chemical properties of the substrates and their components. ${ }^{2}$

\begin{tabular}{lcccccc}
\hline Substrate/component & $\mathrm{N}(\%)$ & $\mathrm{P}\left(\mathrm{mg} \cdot \mathrm{kg}^{-1}\right)$ & $\mathrm{K}\left(\mathrm{mg} \cdot \mathrm{kg}^{-1}\right)$ & $\mathrm{Mg}\left(\mathrm{mg} \cdot \mathrm{kg}^{-1}\right)$ & $\mathrm{Na}\left(\mathrm{mg} \cdot \mathrm{kg}^{-1}\right)$ & $\mathrm{Ca}\left(\mathrm{mg} \cdot \mathrm{kg}^{-1}\right)$ \\
\hline 2T:3S:5P & 0.46 & 15.7 & 42.3 & 81 & 45 & 524 \\
2C:3S:5P & 1.58 & 103 & 1,066 & 163 & 421 & 646 \\
T & 1.06 & 538 & 729 & 2,335 & 1,217 & 5,380 \\
C & 2.01 & 1,464 & 15,190 & 2,013 & 5,913 & 3,667 \\
S & 0.05 & $6.8^{*}$ & $62^{* *}$ & $62^{* *}$ & $39 * *$ & $986^{* *}$ \\
\hline
\end{tabular}

${ }^{2}$ Total concentrations are presented except those indicated by *P-Olsen and $* *$ exchangeable metal forms. $\mathrm{N}=$ nitrogen $; \mathrm{P}=$ phosphorus; $\mathrm{K}=$ potassium; $\mathrm{Mg}=$ magnesium; $\mathrm{Na}=$ sodium $; \mathrm{Ca}=$ calcium $; \mathrm{T}=$ peat $\mathrm{S}=$ soil; $\mathrm{P}=$ perlite; $\mathrm{C}=$ grape marc compost, ratios by volume.

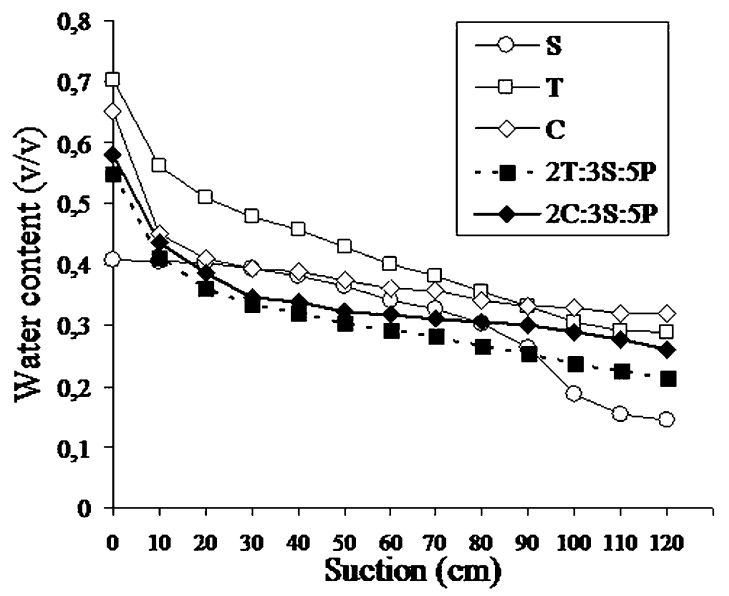

Fig. 1. Water retention curves of the substrates, 2T:3S:5P, 2C:3S:5P (ratio by volume) and their components, grape marc compost $(\mathrm{C})$, peat $(\mathrm{T})$, and soil $(\mathrm{S})$. tests were carried out until 15 July. From 15 July automatic drip irrigation on the surface of the media started. Irrigation was applied before sunrise by two drippers placed at equal distances from the center of the container and the plants (dripper supply $3.3 \mathrm{~L} \cdot \mathrm{h}^{-1}$, irrigation period: $25 \mathrm{~min}$ for shallow and $45 \mathrm{~min}$ for deep substrate, adequate to allow water to drain off the container). Irrigation stopped on 5 Oct.

The ambient average temperature, relative humidity, total radiation, and precipitation (Table 1) were recorded by the Laboratory of General and Agricultural Meteorology at the Agricultural University of Athens. During the water stress period applied to the experimental plants in June, July, and August, there were only four incidents of rain, 0.6 to $0.8 \mathrm{~mm}$ each (Table 1 ), and they did not affect irrigation treatments.

Plant growth evaluation. Plant growth was evaluated monthly measuring plant height (from a mark put at planting on each container at substrate level) and plant diameter (average of the biggest diameter and its perpendicular). Flowering was very limited (only seven $H$. italicum plants flowered, five of them in compost-amended substrates) and therefore flowering data are not recorded. At the end of the experiment on 21 Oct. (5 months after planting), the dry weight of the aboveground part of the plant was determined. The aboveground part of each plant was cut at the substrate surface, put in a paper bag, and placed in a drying oven at $72{ }^{\circ} \mathrm{C}$ for 4 $\mathrm{d}$, after which the dry weight was measured. The dry weight of the roots was not recorded because part of the rooting system had penetrated into the layers used to simulate a green roof system at the bottom of each container.

Substrate characteristics. The physical and chemical properties of the substrates and their components were measured in three samples before planting and the means are shown in Tables 2 and 3 and in Figure 1. Substrate $\mathrm{pH}$ and electrical conductivity (EC) were determined in 1:5 volume water extracts [Federal Compost Quality Assurance Organization (FCQAO), 1994] by the methods of Peech (1965) and Bower and Wilcox (1965), respectively. The physical properties of the substrates were determined after $48 \mathrm{~h}$ saturation. Samples were prepared by the methods described in FCQAO (1994). Bulk density, porosity, and water retention were evaluated by the methods of Blake and Hartge (1986), Danielson and Sutherland (1986), and Klute (1986), respectively. Easily available water was determined from water retention curves as the quantity of water released when the suction was increased from 10 to $50 \mathrm{~cm}$.

In peat and in compost, total $\mathrm{N}$ measurements were performed following the Kjeldahl method (Karla, 1998), while for the determination of total $\mathrm{P}, \mathrm{K}$, calcium $(\mathrm{Ca})$, magnesium $(\mathrm{Mg})$, and sodium $(\mathrm{Na})$ concentrations the dry ashing procedure was applied (Karla, 1998). In soil, exchangeable cations (i.e., $\mathrm{Ca}^{2+}, \mathrm{Mg}^{2+}$, $\mathrm{K}^{+}, \mathrm{Na}^{+}$) were determined by the $\mathrm{NH}_{4}$-acetate method (Thomas, 1982), plant-available $P$ was determined according to Olsen et al. (1954), 
and total $\mathrm{N}$ was titri-metrically measured after the distillation of $\mathrm{NH}_{3}$ using the Kjeldahl digestion (Bremner and Mulvaney, 1982). Spectrophotometry was used to quantify $\mathrm{P}$ (Milton Roy; Spectronic 401, Ivyland, PA), $\mathrm{K}$ and $\mathrm{Na}$ were quantified by flame emission spectroscopy (Corning, Flame Photometer 410, Corning, NY), and $\mathrm{Ca}$ and $\mathrm{Mg}$ by atomic absorption spectrophotometry (Varian SpectrAA 300). The results were expressed by weight.

The saturated weights at $7.5-\mathrm{cm}$ depth of the substrates, including or not the layers to simulate a green roof infrastructure, are shown on Table 4. These weights are lower

Table 4. Saturated weights at 7.5-cm depth of the substrates and the layers to simulate a green roof infrastructure.

\begin{tabular}{lcc}
\hline Substrate & $\begin{array}{c}\text { Substrate wt } \\
\left(\mathrm{kg} \cdot \mathrm{m}^{-2}\right)\end{array}$ & $\begin{array}{r}\text { Substrate + layers } \\
\text { wt }\left(\mathrm{kg} \cdot \mathrm{m}^{-2}\right)\end{array}$ \\
\hline 2T:3S:5P & 47 & 62 \\
2C:3S:5P & 63 & 78
\end{tabular}

$\mathrm{T}=$ peat; $\mathrm{S}=$ soil; $\mathrm{P}=$ perlite $; \mathrm{C}=$ grape marc compost, ratios by volume. than what is considered acceptable for extensive green roofs (Dunnett and Kingsbury, 2008; Fassman et al., 2010). The substrate weights were evaluated before planting and do not include the weight of the containers (the latter being 1.6 and $1.9 \mathrm{~kg}$ for the shallow and the deep container, respectively).

Statistical analysis. Three multifactorial experiments, one for each plant species, with three factors each were conducted. The three factors were: substrate type (peat or compostamended), substrate depth (15 or $7.5 \mathrm{~cm})$, and irrigation frequency (normal or sparse). Therefore, eight treatments were applied $\left(2_{\text {substrats }} \times 2_{\text {depths }} \times 2_{\text {irrigations }}\right)$. The containers were arranged following the completely randomized design. The significance of the results was tested by three-way analysis of variance (ANOVA) ( $F$ test, discrete variables followed the normal distribution). The treatment means were compared using Fisher's least significant difference or Student's $t$ test at $P \leq 0.05$. JMP Version 8 statistical software (SAS Institute Inc., Cary, NC) was used.
A

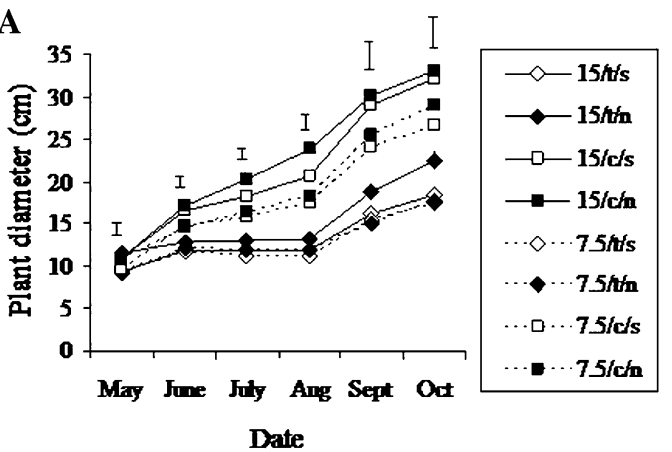

B
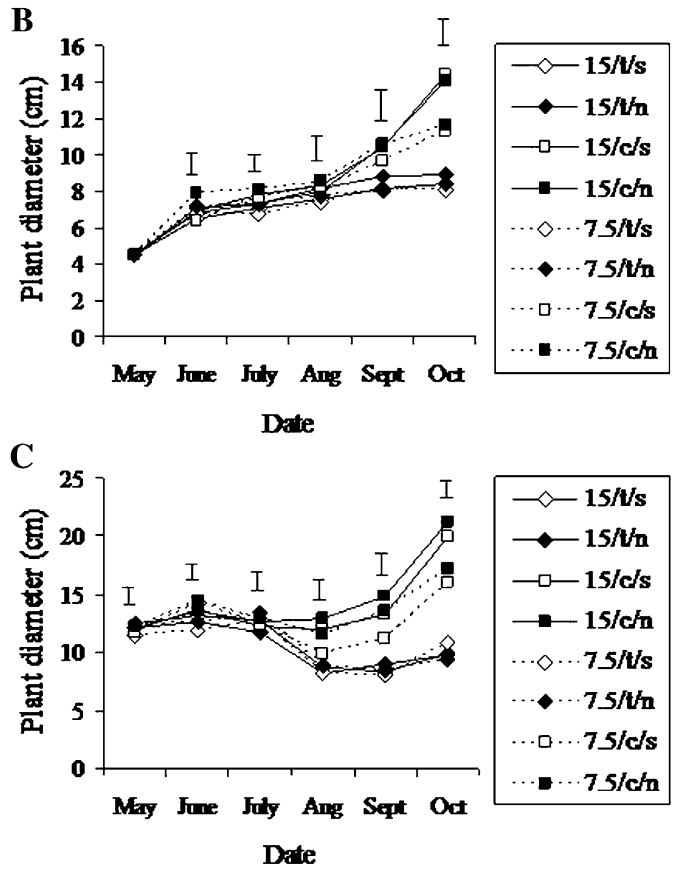

Fig. 2. Effect of the experimental treatments that consist of combinations of irrigation frequency $(n=$ normal or $\mathrm{s}=$ sparse $)$, substrate type $(\mathrm{t}=$ peat-amended substrate or $\mathrm{c}=$ grape mark compost-amended substrate) and substrate depth $(15 \mathrm{~cm}$ or $7.5 \mathrm{~cm})$ on plant diameter $(\mathrm{cm})$ during the 5 -month culture period of A. absinthium (A), H. italicum (B), and H. orientale $(\mathbf{C})$ at a Mediterranean green roof. Mean comparison at each date with Fisher's least significant difference (LSD) at $P \leq 0.05$.

\section{Results and Discussion}

All three plant species were established successfully on the green roof under all experimental treatments, whereas in general $A$. absinthium had the greatest growth, as indicated by the final diameter and height of the plants (Figs. 2 and 3). In all three species, three-way ANOVA of data concerning the various plant growth parameters measured 5 months after planting showed that there was no interaction of the main experimental factors (Table 5). However, two-way ANOVA indicated significant interactions in 10 of the 27 paired comparisons of the main factors, that is, six between substrate type and depth, three between substrate type and irrigation frequency, and only one between substrate depth and irrigation frequency (Table 5). In A. absinthium, there were no interactions of the main factors apart from an interaction of substrate type and depth in plant dry weight. Thus, in this species, grape marc compostamended substrate produced taller plants and larger plant diameter compared with peatamended substrate, deep substrate produced larger plant diameter compared with shallow substrate, and normal irrigation produced taller plants compared with sparse irrigation. In both Helichrysum sp., there were interactions of the main factors in almost all growth parameters; therefore, the only conclusion concerning factor effects was that irrigation frequency did not affect the diameter and the dry weight of $H$. italicum plants. Plant diameter and dry weight are the most important indicators of successful plant growth on a green roof (Molineux et al., 2009); therefore, irrigation frequency did not seem to affect the establishment of $H$. italicum on the green roof, whereas grape marc compost and deep substrate promoted the establishment of A. absinthium.

Beneficial effects of deeper substrates on plant growth in extensive and semiextensive green roof systems have been reported by a number of researchers (Dunnett et al., 2007; Durhman et al., 2007; Getter and Rowe, 2008, 2009; Nektarios et al., 2011; Thuring et al., 2010; VanWoert et al., 2005) and were mainly attributed to increased waterholding capacity, because shallower substrates lose their moisture faster during a drought period. In the present work, there were no significant interactions between substrate depth and irrigation frequency with an exception in $H$. orientale height (Table 5); thus, in shallow substrates, normal irrigation did not produce bigger growth compared with sparse irrigation (Table 6). Therefore, the bigger plant diameter of $A$. absinthium in deep substrate could be attributed to higher nutrient availability, possibility supported by the significant interaction of substrate type and depth in most of the growth parameters measured (Table 5).

Concerning the effect of each experimental treatment on plant growth, the highest values of all growth parameters were recorded in plants cultured in deep substrate amended with compost. Under this growth-favoring 
A

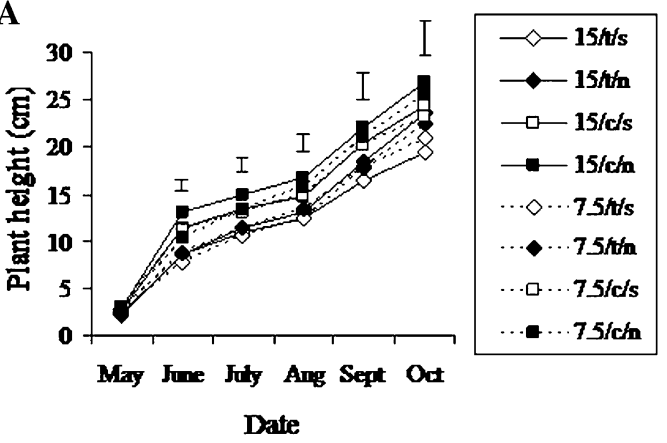

B

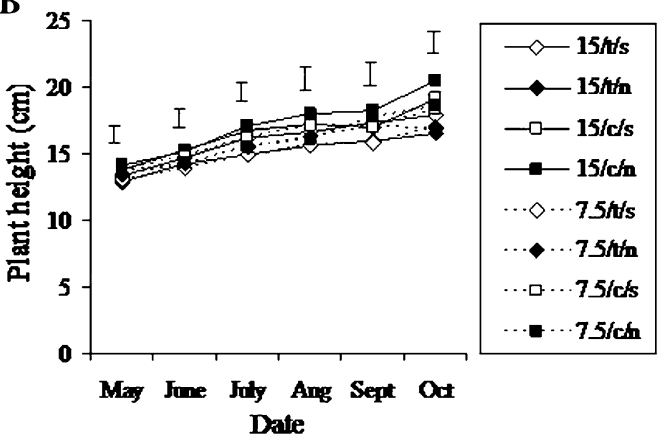

C

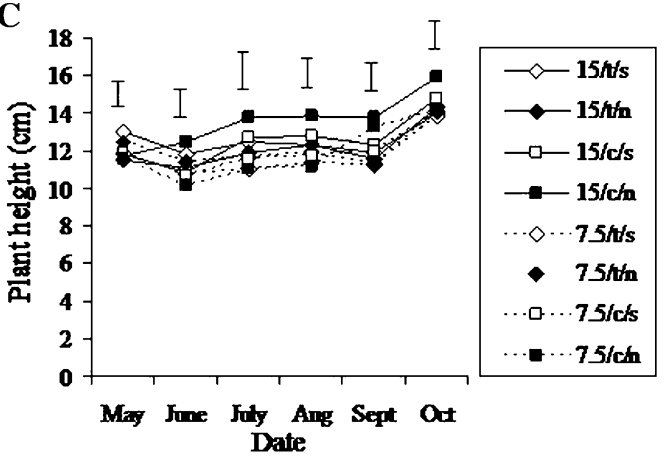

Fig. 3. Effect of the experimental treatments that consist of combinations of irrigation frequency $(n=$ normal or $\mathrm{s}=$ sparse $)$, substrate type $(\mathrm{t}=$ peat-amended substrate or $\mathrm{c}=$ grape mark compost-amended substrate) and substrate depth $(15 \mathrm{~cm}$ or $7.5 \mathrm{~cm})$ on plant height $(\mathrm{cm})$ during the 5-month culture period of A. absinthium (A), H. italicum (B), and H. orientale (C) at a Mediterranean green roof. Mean comparison at each date with Fisher's least significant difference (LSD) at $P \leq 0.05$.

Table 5. The effect of the main experimental factors, i.e., irrigation frequency (normal or sparse), substrate type (peat or compost-amended), and substrate depth $(15 \mathrm{~cm}$ or $7.5 \mathrm{~cm})$ on aboveground dry weight (dry wt, $\mathrm{g}$ ), height increase $(\mathrm{h}, \mathrm{cm})$, and diameter increase $(\mathrm{d}, \mathrm{cm})$ of the three plant species shown after 5 months' culture on a Mediterranean green roof.

\begin{tabular}{|c|c|c|c|c|c|c|c|c|c|}
\hline \multirow[b]{2}{*}{ Main factors } & \multicolumn{3}{|c|}{ A. absinthium } & \multicolumn{3}{|c|}{ H. italicum } & \multicolumn{3}{|c|}{ H. orientale } \\
\hline & dry wt & $\mathrm{h}$ & $\mathrm{d}$ & dry wt & $\mathrm{h}$ & $\mathrm{d}$ & dry wt & $\mathrm{h}$ & $\mathrm{d}$ \\
\hline Normal & $14 \mathrm{a}$ & $22 \mathrm{a}$ & $15 \mathrm{a}$ & $8 \mathrm{a}$ & 5 & $4 \mathrm{a}$ & 11 & 3 & 2 \\
\hline Sparse & $12 \mathrm{a}$ & $19 \mathrm{~b}$ & $14 \mathrm{a}$ & $9 \mathrm{a}$ & 5 & $4 \mathrm{a}$ & 9 & 2 & 2 \\
\hline $2 \mathrm{~T}: 3 \mathrm{~S}: 5 \mathrm{P}$ & 6 & $19 \mathrm{~b}$ & $9 \mathrm{~b}$ & 6 & 4 & 2 & 5 & 2 & -2 \\
\hline $2 \mathrm{C}: 3 \mathrm{~S}: 5 \mathrm{P}$ & 19 & $22 \mathrm{a}$ & $20 \mathrm{a}$ & 12 & 5 & 6 & 15 & 3 & 6 \\
\hline $15 \mathrm{~cm}$ & 15 & $20 \mathrm{a}$ & $16 \mathrm{a}$ & 10 & $5 \mathrm{a}$ & 5 & 12 & 3 & 3 \\
\hline $7.5 \mathrm{~cm}$ & 11 & $21 \mathrm{a}$ & $13 \mathrm{~b}$ & 7 & $4 a$ & 3 & 8 & 2 & 1 \\
\hline Firrigation & NS & $*$ & NS & NS & NS & NS & - & 一 & - \\
\hline$F$ substrate & - & $*$ & $*$ & - & $*$ & - & - & - & - \\
\hline$F$ depth & - & NS & $*$ & - & NS & - & - & - & - \\
\hline Firrigation $\times$ substrate & NS & NS & NS & NS & $*$ & NS & $*$ & NS & * \\
\hline Firrigation $\times$ depth & NS & NS & NS & NS & NS & NS & NS & $*$ & NS \\
\hline$F$ substrate $\times$ depth & $*$ & NS & NS & $*$ & NS & $*$ & $*$ & $*$ & $*$ \\
\hline Firrigation $\times$ substrate $\times$ depth & NS & NS & NS & NS & NS & NS & NS & NS & NS \\
\hline
\end{tabular}

${ }^{\mathrm{z}}$ Mean comparison in columns within each main factor with Student's $t$ test at $P \leq 0.05$; means followed by the same letter are not significantly different at $P \leq 0.05$.

*Significant at $P \leq 0.05$; NS $=$ nonsignificant.

$\mathrm{T}=$ peat $\mathrm{S}=$ soil $; \mathrm{P}=$ perlite $; \mathrm{C}=$ grape marc compost, substrate ratios by volume. combination, which resulted in the production of more foliage, sparse irrigation became a limiting factor and affected negatively the aboveground dry weight of $A$. absinthium and $H$. orientale as well as the height of $H$. orientale (Table 6). In deep peat-amended substrate, plant growth was small and sparse irrigation affected negatively only the height of $A$. absinthium. Plants also grew quite well in shallow substrates amended with grape marc compost independent of irrigation frequency. In general, irrigation frequency did not affect plant growth in shallow substrates apart from some rather contradictory effects on the diameter of both Helichrysum sp. (Table 6). In all three species, treatments that included the use of compost promoted an increase of plant diameter and yielded the largest plant dry weights, whereas treatments that included the use of deeper substrate resulted in increased plant dry weights only when the substrate was amended with compost. Both of these effects were independent of irrigation frequency (Table 6). The lack of significant growth restriction by reduced irrigation during the summer period is in accordance with previous results in the Mediterranean xerophyte Dianthus fruticosus under similar experimental conditions (Nektarios et al., 2011).

The organic content in the substrates was in accordance with the FLL (2010) guidelines for extensive green roofs. The beneficial effect of grape marc compost on plant growth was in agreement with previous findings for potted ornamentals and greenhouse tomato culture (Papafotiou et al., 2011a, 2011b; Reis et al., 2001) and could be attributed mainly to its increased concentration of nutrients compared with peat substrate (Table 3). However, the $\mathrm{K} / \mathrm{Mg}$ rate in the compost substrate was high (6.6) and this could have led to a suppressive effect of $\mathrm{K}$ on $\mathrm{Mg}$ plant uptake (Bunt, 1988). This could explain the chlorosis observed on old leaves of both Helichrysum sp. plants in late June and $H$. orientale in early September when growth was relatively larger (Figs. 2B, 2C, and 3C). Helichrysum sp. showed the same symptoms in peat substrate too, probably because of the low Mg concentration in this substrate. In all cases, plants recovered soon after fertilization.

The $\mathrm{pH}$ of the substrates should not have affected nutrient absorption. The rather high $\mathrm{pH}$ values determined (Table 2 ) are attributable partly to the method used (FCQAO, 1994), which uses 1:5 volume water extracts that give higher $\mathrm{pH}$ values to the commonly used $1: 2$ or $1: 2.5$ volume water extracts. The physical characteristics of the substrates were similar (Table 2; Fig. 1) and should not have yielded differences in plant growth.

The roots of the plants after the first 1 to 2 months from planting penetrated all three layers placed at the bottom of each container to simulate a green roof system but remained restricted in each container, because of the root repellent membrane placed between the containers and the roof. Because roots were able to directly draw water from the drainage layer and the moisture retention layer, substrate 
Table 6. The effect of the experimental treatments that consist of combinations of irrigation frequency (normal or sparse), substrate type (peat or compost-amended), and substrate depth (15 cm or $7.5 \mathrm{~cm})$ on aboveground dry weight (dry wt, g), height increase $(\mathrm{h}, \mathrm{cm})$, and diameter increase $(\mathrm{d}, \mathrm{cm})$ of the three plant species shown after 5 months' culture on a Mediterranean green roof. ${ }^{z}$

\begin{tabular}{|c|c|c|c|c|c|c|c|c|c|}
\hline \multirow[b]{2}{*}{ Treatment } & \multicolumn{3}{|c|}{ A. absinthium } & \multicolumn{3}{|c|}{ H. italicum } & \multicolumn{3}{|c|}{ H. orientale } \\
\hline & dry wt & $\mathrm{h}$ & $\mathrm{d}$ & dry wt & $\mathrm{h}$ & $\bar{d}$ & dry wt & $\mathrm{h}$ & $\mathrm{d}$ \\
\hline $15 / \mathrm{t} / \mathrm{n}$ & $8 d$ & $21 \mathrm{ab}$ & $11 \mathrm{~b}$ & $6 \mathrm{~cd}$ & $3.7 \mathrm{~cd}$ & $2 \mathrm{~d}$ & $6 \mathrm{de}$ & $2.8 \mathrm{~b}$ & $-2 \mathrm{de}$ \\
\hline $15 / \mathrm{c} / \mathrm{n}$ & $25 \mathrm{a}$ & $24 \mathrm{a}$ & $22 \mathrm{a}$ & $13 \mathrm{a}$ & $6.4 \mathrm{a}$ & $7 \mathrm{a}$ & $19 \mathrm{a}$ & $4.2 \mathrm{a}$ & $9 \mathrm{a}$ \\
\hline $15 / \mathrm{t} / \mathrm{s}$ & $6 \mathrm{~d}$ & $17 \mathrm{c}$ & $9 \mathrm{~b}$ & $7 \mathrm{c}$ & $4.6 \mathrm{bcd}$ & $2 \mathrm{~d}$ & $6 \mathrm{~d}$ & $1.0 \mathrm{~d}$ & $-3 \mathrm{de}$ \\
\hline $15 / \mathrm{c} / \mathrm{s}$ & $22 \mathrm{~b}$ & $22 \mathrm{ab}$ & $21 \mathrm{a}$ & $14 \mathrm{a}$ & $5.3 \mathrm{ab}$ & $8 \mathrm{a}$ & $17 \mathrm{~b}$ & $3.0 \mathrm{~b}$ & $8 \mathrm{a}$ \\
\hline $7.5 / \mathrm{t} / \mathrm{n}$ & $6 \mathrm{~d}$ & $19 \mathrm{c}$ & $8 \mathrm{~b}$ & $5 \mathrm{~d}$ & $3.5 \mathrm{~d}$ & $1 \mathrm{~d}$ & $5 \mathrm{~d} \mathrm{e}$ & $1.6 \mathrm{~cd}$ & $-3 \mathrm{e}$ \\
\hline $7.5 / \mathrm{c} / \mathrm{n}$ & $16 \mathrm{c}$ & $23 \mathrm{ab}$ & $18 \mathrm{a}$ & $9 \mathrm{~b}$ & $4.9 \mathrm{bc}$ & $4 \mathrm{c}$ & $12 \mathrm{c}$ & $2.7 \mathrm{bc}$ & $5 \mathrm{~b}$ \\
\hline $7.5 / \mathrm{t} / \mathrm{s}$ & $6 d$ & $18 \mathrm{c}$ & $9 \mathrm{~b}$ & $5 \mathrm{~d}$ & $4.2 \mathrm{bcd}$ & $2 d$ & $4 \mathrm{e}$ & $2.0 \mathrm{bcd}$ & $-1 \mathrm{~cd}$ \\
\hline $7.5 / \mathrm{c} / \mathrm{s}$ & $15 \mathrm{c}$ & $20 \mathrm{bc}$ & $17 \mathrm{a}$ & $10 \mathrm{~b}$ & $4.5 \mathrm{bcd}$ & $5 \mathrm{~b}$ & $10 \mathrm{c}$ & $1.6 \mathrm{~cd}$ & $2 \mathrm{c}$ \\
\hline
\end{tabular}

${ }^{\mathrm{z}}$ Mean comparison in columns with Student's $t$ test at $P \leq 0.05$; means followed by the same letter are not significantly different at $P \leq 0.05$.

$\mathrm{t}=$ peat-amended substrate $; \mathrm{c}=$ grape marc compost-amended substrate $; \mathrm{s}=$ sparse irrigation; $\mathrm{n}=$ normal irrigation.

moisture, which was very low $(6.5 \%$ to $8.5 \%$ $\mathrm{v} / \mathrm{v}$ ) before each irrigation event in the sparse irrigation treatments, may have not been as influential as it would without this particular infrastructure. Apparently this is part of the advantage of using this infrastructure in green roofs, because it allows part of the drained water to be reused by the plants. Recently, Savi et al. (2013) working on a similar green roof system in the Mediterranean showed that during the dry period, substrate and water retention layer retained, respectively, $34 \%$ and $90 \%$ in volume of water potentially available to plants and that the moisture retention layer and the drainage layer significantly influenced the amount of water available to plants, particularly to shallower substrates.

Concerning the monthly increase of plant diameter (Fig. 2) during the drought period (June to August), A. absinthium continued to grow only in treatments where the substrate was amended with compost, particularly that combining compost with increased depth and normal irrigation (Fig. 2A), whereas $H$. italicum in all treatments had minimal horizontal growth (Fig. 2B). H. orientale did not modify its diameter in treatments with deep compost substrate (independent of irrigation frequency) and decreased it in all treatments with peat substrate and in that with shallow and sparsely irrigated compost substrate (Fig. $2 \mathrm{C})$. The latter was the result of leaf curling and some loss of lower older leaves, a common response of Mediterranean xerophytes to drought. Both Helichrysum sp. grown in compost-amended substrates, independent of substrate depth and irrigation, responded quickly to September temperature drop and rainfall events producing lateral shoots that resulted in plant diameter increase, something that did not occur in treatments with peat substrates (Fig. 2B-C). A. absinthium plant diameter increased in all treatments in response to season change (Fig. 2A).

Plant height may not be as important as plant diameter and dry weight for determining plant success on a green roof, although taller plants such as plants of larger diameter may be more effective in reducing water runoff from green roofs (Nagase and Dunnett, 2012). In all treatments, $A$. absinthium and
H. italicum had slightly increased height even during the drought period (Fig. 3A-B). The height of $A$. absinthium increased more in treatments including compost substrate, similarly in all treatments. H. orientale increased its height only after the drought period, apart from plants in deep compostamended substrate under normal irrigation that showed height increase from May to July, too (Fig. 3C).

An interesting outcome of this work was with sparse irrigation resulted in similar or even bigger growth, in all species, compared with deep peat-amended substrate with normal irrigation (Table 6; Figs. 2 and 3). This was true for all growth parameters measured except plant height of $H$. orientale. Apart from $\mathrm{N}$, the high $\mathrm{K}$ concentration in the compost-amended substrate (Table 3) was possibly determinant for plant growth, helping to overcome the adverse conditions of the green roof as drought, heat, and wind (Cakmak 2005; Egilla et al., 2001). Apart from this, in A. absinthium, growth of plant diameter during the drought period in treatments with compost (Figs. 2 and 3) led to faster cover of the substrate surface that could have resulted in a reduction of water evaporation from the substrate and thus to an increase of the moisture-retaining capacity of it and better use of water by the plants leading to further growth.

In conclusion, the aromatic xerophytes $A$. absinthium, $H$. italicum, and $H$. orientale were found suitable for growth in extensive Mediterranean green roofs under limited irrigation and substrate depth $(7.5 \mathrm{~cm})$. Including $20 \%(\mathrm{v} / \mathrm{v})$ grape marc compost in the substrate enhanced plant establishment and growth during the first drought period.

\section{Literature Cited}

Alexander, P.D., N.C. Bragg, R. Meade, G. Padelopoulos, and O. Watts. 2008. Peat in horticulture and conservation: The UK response to a changing world. Mires and Peat Volume 3, Article 08. <http://www.mires-and-peat.net/>. ISSN 1819-754X. (c) 2008 International Mire Conservation Group and International Peat Society. whereas $H$. italicum height increased rather that shallow compost-amended substrate
Ampim, P.A.Y., J.J. Sloan, R.I. Cabrera, D.A. Harps, and F.H. Jabers. 2010. Green roof growing substrates: Types, ingredients. Composition and properties. J. Environ. Hort. 28:244-252.

Benvenuti, S. and D. Bacci. 2010. Initial agronomic performances of Mediterranean xerophytes in simulated dry green roofs. Urban Ecosyst. 13:349-363.

Blake, G.R. and K.H. Hartge. 1986. Bulk density, p. 363-376. In: Klute, A. (ed.). Methods of soil analysis: Part 1-Physical and mineralogical methods. SSSA, Madison, WI.

Bower, C.A. and L.V. Wilcox. 1965. Soluble salts, p. 933-951. In: Black, C.A. (ed.). Methods of soil analysis: Part 2-Chemical and microbiological properties. ASA, Madison, WI.

Bowler, D.E., L. Buyung-Ali, T.M. Knight, and A.S. Pullin. 2010. Urban greening to cool towns and cities: A systematic review of the empirical evidence. Landsc. Urban Plan. 97: 147-155.

Bremner, J.M. and C.S. Mulvaney. 1982. Total nitrogen, p. 595-615. In: Page, A.L., R.H. Miller, D.R. Keeney (eds.). Methods of soil analysis, Part 2. Chemical and microbiological properties. ASA, SSSA, Madison, WIA.

Bunt, A.C. 1988. Media and mixes for container grown plants: A manual on the preparation and use of growing media for pot plants. Unwin Hyman, London, UK.

Butler, C. and C.M. Orians. 2011. Sedum cools soil and can improve neighbouring plant performance during water deficit on a green roof. Ecol. Eng. 37:1796-1803.

Cakmak, I. 2005. The role of potassium in alleviating detrimental effects of abiotic stresses in plants. J. Plant Nutr. Soil Sci. 168:521-530.

Chiasson, H., A. Bélanger, N. Bostanian, C. Vincent, and A. Poliquin. 2001. Acaricidal properties of Artemisia absinthium and Tanacetum vulgare (Asteraceae) essential oils obtained by three methods of extraction. J. Econ. Entomol. 94: 167-171.

Cook-Patton, S.C. and T.L. Bauerle. 2012. Potential benefits of plant diversity on vegetated roofs: A literature review. J. Environ. Mgt. 106:85-92.

Currie, B.A. and A.C. Bass. 2008. Estimates of air pollution mitigation with green plants and green roofs using the UFORE model. Urban Ecosyst. 11:409-422.

Danielson, R.E. and P.L. Sutherland. 1986. Porosity: Methods of soil analysis, Part 1-Rev. Physical and Mineralogical Methods. ASA, Monogr. 9.

Dunnett, N., A. Nagase, and A. Hallam. 2007. The dynamics of planted and colonising species on a green roof over six growing seasons 20012006: Influence of substrate depth. Urban Ecosyst. 11:373-384.

Dunnett, N.P. and N. Kingsbury. 2008. Planting green roofs and living walls. 2nd Ed. Timber Press, Portland, OR.

Durhman, A.K., D.B. Rowe, and C.L. Rugh. 2007. Effect of substrate depth on initial growth, coverage, and survival of 25 succulent green roof plant taxa. HortScience 42:588-595.

Dvorak, B. and A. Volder. 2010. Green roof vegetation for North American ecoregions: A literature review. Landsc. Urban Plan. 96:197-213.

Egilla, J.N., F.T. Davies, and M.C. Drew. 2001. Effect of potassium on drought resistance of Hibiscus rosa-sinensis cv. Leprechaun: Plant growth, leaf macro- and micronutrient content and root longevity. Plant Soil 229:213-224.

Fassman, E.A., R. Simcock, and E. Voyde. 2010. Extensive green (living) roofs for stormwater 
mitigation: Part 1 design and construction. Prepared by Auckland UniServices for Auckland Regional Council. Auckland Regional Council Technical Report 2010/017.

Federal Compost Quality Assurance Organization. 1994. Methods book for the analysis of compost: Kompost-Information. No. 230. Budesgutegemeinschaft Kompost e.v., Stuttgart, Germany.

Fioretti, R., A. Palla, L.G. Lanza, and P. Principi. 2010. Green roof energy and water related performance in the Mediterranean climate. Build. Environ. 45:1890-1904.

FLL. 2010. Guideline for the planning, execution and upkeep of green-roof sites [English ed.]. Forschungsgesellschaft Landschaftsentwicklung Landschaftsbau.

Fussell, M. and S. Corbet. 1992. The nesting places of some British bumblebees. J. Agr. Res. 31: $32-41$.

Getter, K.L. and D.B. Rowe. 2006. The role of extensive green roofs in sustainable development. HortScience 41:1276-1285.

Getter, K.L. and D.B. Rowe. 2008. Media depth influences Sedum green roof establishment. Urban Ecosyst. 11:361-372.

Getter, K.L. and D.B. Rowe. 2009. Substrate depth influences Sedum plant community on a green roof. HortScience 44:401-407.

Getter, K.L., D.B. Rowe, G.P. Robertson, B.M. Cregg, and J.A. Andersen. 2009. Carbon sequestration potential of extensive green roofs. Environ. Sci. Technol. 43:7564-7570.

Jaffal, I., S.E. Ouldboukhitine, and R. Belarbi. 2012. A comprehensive study of the impact of green roofs on building energy performance. Renew. Energy 43:157-164.

Karla, P.Y. 1998. Handbook of reference methods for plant analysis. CRC Press.

Klute, A. 1986. Methods of soil analysis: Part 1, Rev. physical and mineralogical methods. ASA, Monogr. 9.

Kotsiris, G., P.A. Nektarios, and A.T. Paraskevopoulou. 2012. Lavandula angustifolia growth and physiology is affected by substrate type and depth when grown under Mediterranean semi-intensive green roof conditions. HortScience 47:311-317.

Kweon, B.-S., W.C. Sullivan, and A.R. Wiley. 1998. Green common spaces and the social integration of inner-city older adults. Environ. Behav. 30:832-858.

Lafuma, L., M.M. Lambrechts, and M. Raymond. 2001. Aromatic plants in bird nests as a protection against blood-sucking flying insects. Behav. Processes 56:113-120.

Li, J., O.H.W. Wai, Y.S. Li, J. Zhan, Y.A. Ho, J. Li, and E. Lamm. 2010. Effect of green roof on ambient $\mathrm{CO}_{2}$ concentration. Build. Environ. 45:2644-2651.

Lundholm, J.T. and S.W. Peck. 2008. Frontiers of green roof ecology. Urban Ecosyst. 11:335-337.

Mackey, C.W., X. Lee, and R.B. Smith. 2012. Remotely sensing the cooling effects of city scale efforts to reduce urban heat island. Built Environ. 49:348-358.

Maclvor, J.S. and J. Lundholmb. 2011. Performance evaluation of native plants suited to extensive green roof conditions in a maritime climate. Ecol. Eng. 37:407-417.

Molineux, C.J., C.H. Fentiman, and A.C. Gange. 2009. Characterising alternative recycled waste materials for use as green roof growing media in the U.K. Ecol. Eng. 35:1507-1513.

Nagase, A. and N. Dunnett. 2010. Drought tolerance in different vegetation types for extensive green roofs: Effects of watering and diversity. Landsc. Urban Plan. 97:318-327.

Nagase, A. and N. Dunnett. 2011. The relationship between percentage of organic matter in substrate and plant growth in extensive green roofs. Landsc. Urban Plan. 103:230-236.

Nagase, A. and N. Dunnett. 2012. Amount of water runoff from different vegetation types on extensive green roofs: Effects of plant species, diversity and plant structure. Landsc. Urban Plan. 104:356-363.

Nagase, A. and N. Dunnett. 2013. Establishment of an annual meadow on extensive green roofs in the UK. Landsc. Urban Plan. 112:50-62.

Nektarios, P.A., I. Amountzias, I. Kokkinou, and N. Ntoulas. 2011. Green roof substrate type and depth affect the growth of the native species Dianthus fruticosus under reduced irrigation regimens. HortScience 46:1208-1216.

Nelson, D.M. 2012. Carbon isotopic composition of Ambrosia and Artemisia pollen: Assessment of a C-3-plant paleophysiological indicator. New Phytol. 195:787-793.

Oberndorfer, E., J. Lundholm, B. Bass, R.R. Coffman, H. Doshi, N. Dunnett, S. Gaffin, M. Kohler, K.K.Y. Liu, and B. Rowe. 2007. Green roofs as urban ecosystems: Ecological structures, functions, and services. Bioscience 57:823-833.

Olsen, S.R., C.V. Cole, F.S. Watanabe, and L.A. Dean. 1954. Estimation of available phosphorus in soils by extracting with sodium bicarbonate. USDA Circ. 939. U.S. Gov. Print. Office, Washington, DC.

Papafotiou, M., E.A. Papanastassatos, I. Massas, and I. Chatzipavlidis. 2011a. Effect of three composts from agroindustrial wastes and inorganic fertilization on nutrition of Codiaeum variegatum. Proc. Hellenic Soc. Hortic. Sci. 14(b):437-442.

Papafotiou, M., N. Pergialioti, I. Massas, and I. Chatzipavlidis. 2011b. Combined effect of inorganic fertilization and various composts from agroindustrial wastes on Ficus benjamina growth. Proc. Hellenic Soc. Hortic. Sci. 14(b): 443-448.

Peech, M. 1965. Hydrogen-ion activity, p. 914 925. In: Black, C.A. (ed.). Methods of soil analysis, Part 2-Chemical and microbiological properties. ASA, Madison, WI.

Polunin, O. 1981. The concise flowers of Europe. Oxford University Press, London, UK.

Reis, M., H. Inácio, A. Rosa, J. Caccedilio, and A. Monteiro. 2001. Grape marc compost as an alternative growing media for greenhouse tomato. Acta Hort. 554:75-82.

Roussis, V., M. Tsoukatou, P.V. Petrakis, I. Chinou, M. Skoula, and J.B. Harborne. 2000. Volatile constituents of four Helichrysum species growing in Greece. Biochem. Syst. Ecol. 28:163-175.

Rowe, D.B., K.L. Getter, and A.K. Durhman. 2012. Effect of green roof media depth on Crassulacean plant succession over seven years. Landsc. Urban Plan. 104:310-319.

Sala, A., M. Recio, R.-M. Giner, S. Máñez, H. Tournier, G. Schinella, and J.-L. Ríos. 2002. Anti-inflammatory and antioxidant properties of Helichrysum italicum. J. Pharm. Pharmacol. 54:365-371.

Savi, T., S. Andri, and A. Nardini. 2013. Impact of different green roof layering on plant water status and drought survival. Ecol. Eng. 57:188-196.

Thomas, G.W. 1982. Exchangeable cations, p. 159-166. In: Page, A.L., R.H. Miller, and D.R. Keeney (eds.). Methods of soil analysis: Part 2-Chemical and microbiological properties. ASA, SSSA, Madison, WI.

Thuring, C.E., R.D. Berghage, and D.J. Bettie. 2010. Green roof plant responses to different substrate types and depths under various drought conditions. Hort Technology 20:395-401.

VanWoert, N.D., D.B. Rowe, J.A. Andresen, C.L. Rugh, and L. Xiao. 2005. Watering regime and green roof substrate design affect Sedum plant growth. HortScience 40:659-664. 